Отримано: 25 серпня 2021 року

Прорецензовано: 6 вересня 2021 року

Прийнято до друку: 20 вересня 2021 року

e-mail: olga.kachmar@uzhnu.edu.ua

yeromenko.viktoriia@student.uzhnu.edu.ua
Kachmar O. Yu., Yeryomenko V. O. Ideation discourse: means of communicative effect achievement (on the material of TED-platform). Наукові записки Наиіонального університету «Острозька академія»: серія «Філологія». Острог : Вид-во НаУОА, 2021. Вип. 11(79). С. 85-90.

DOI: 10.25264/2519-2558-2021-11(79)-85-90

UDC: $811.111^{\prime} 42$

Olga Kachmar,

PhD in Philology, Associate Professor,

SU "Uzhhorod National University"

Victoria Yeryomenko,

graduate student,

SU "Uzhhorod National University"

\title{
IDEATION DISCOURSE: MEANS OF COMMUNICATIVE EFFECT ACHIEVEMENT (ON THE MATERIAL OF TED-PLATFORM)
}

Interactive aspects of communication include the following categories embodied in the metacommunicative elements of discourse, one of which is speech mode. The article focuses on pattern identification of communicative effect on the recipient by varying serious and humorous modes of the speech. The attention is paid to the identification of the initial strategies of communicative effect in both serious and humorous mode of English ideative speech. Communicative mode is an emotionally-stylistic communication format that occurs during the interaction between communicants and determines their changing attitudes and the choice of all means of communication. Serious mode orients the subjects of discourse to perceive communicative action as the one corresponding to norms. Humorous mode orients the subjects of discourse to perceive communicative action as the one inconsistent with norms. The paper gives results of inferential analysis of responsive actions on how successful the ideators' speeches are according to the recipients' instant and delayed responsive actions. The evaluation of communicative success has been conducted with the help of inferencial analysis of verbal and non-verbal actions of the audience taking into account instant and delayed responsive actions, in particular total number of the recording views, average monthly number of views; laughter, applause, cheers, murmur.

Key words: mode variation, communicative effect, incongruity, ideation discourse, initial strategy, responsive strategy.

\author{
Качмар Ольга Юрї̈вна, \\ кандидат філологічних наук, дочент, \\ ДВНЗ «Ужгородський національний університет» \\ Срьоменко Вікторія Олексіївна, \\ студентка 2-го року магістратури, \\ ДВНЗ «Ужггородський начіональний університет»
}

\section{ДИСКУРС ІДЕАЦЇ̈: ІНСТРУМЕНТИ ДОСЯГНЕННЯ КОМУНІКАТИВНОГО ВПЛИВУ (НА МАТЕРІАЛІ ІНТЕРНЕТ-ПЛАТФОРМИ ТЕD)}

\begin{abstract}
Дослідження зосереджене на виявленні закономірностей комунікативного впливу на реципієнта шляхом варіювання серйозної та гумористичної тональностей у ідеаційній промові (на базі платформи ТЕD). Значна увага приділяється виявленню ініціальних стратегій комунікативного впливу як у серйозній, так і гумористичній тональностях англомовної ідеаційної промови. Оиінка комунікативної успішності вибраних виступів була здійснена за допомогою інферениійного аналізу з урахуванням миттєвих та відстрочених респонсивних дій, зокрема підрахунки загальної кількості переглядів записів, середньомісячної кількості переглядів; загальної кількості миттєвих респонсивних дій, таких як сміх, оплески, схальні вигуки та інші.
\end{abstract}

Ключові слова: варіативність мовної тональності, комунікативний вплив, дискурс ідеації, інконгруентність, ініціальна стратегія, респонсивна стратегія.

Ideation discourse is triggered by a speech, which was given by a participant of TED conference. TED is a media organization that posts talks online for free distribution. Its main aim is to spread ideas, and this is reflected in the motto of the community "ideas worth spreading". At the conferences speakers usually deliver short speeches in English. Each speech suggests a solution to an urgent issue. The idiator's communicative aim is to create communicative effect on the recipients, which is achieved through the communicative strategies of instructing, persuading and informing. Therefore, the topicality of the paper is determined by the tendencies of modern cognitive linguistics that is aimed at studying cognitive-affective-volitional factors that are based on human interaction with the environment and regulate social behavior. The aim of the investigation is to identify the patterns of communicative effect on the recipient by varying serious and humorous mode of the speech. The main objectives of the paper are to provide a definition of English ideation discourse; to identify initial strategies of communicative effect in both serious and humorous mode of English ideative speech; to implement a description of verbal and non-verbal responsive strategies; to deduce salient features of communicatively successful ideative speeches.

The object of our investigation is linguo-cognitive basis of communicative strategies that enables the implementation of communicative influence, oriented on emotions, subconsciousness, volition and rational thinking. The subject is the initial and responsive strategies featured by verbal and non-verbal communicative actions delivered in serious and humorous form.

The methodological basis of the paper is a cognitive-communicative approach to language analysis (G. Lakoff; D. Schiffrin, D. Tannen, H. Hamilton; M. Johnson; T.A. van Dijk, W. K. Date) specified in the works of the domestic linguists (D. Kaysina; M. Polyzhyn; L. Ilnytska; V. Samokhina; A. Martynyuk; O. Morozova).

As the material of the study serve around 120 communicative actions and 21 ideative speeches, duration of which is approximately 4 hours. Recording scripts of the analyzed ideative speeches incorporate 90 standard pages. 
The practical significance of the work is determined by the possibility to use the study results in teaching Cognitive Linguistics, Cognitive Discourse, Sociolinguistics, as well as general courses in Linguistics, Stylistics, or Modern English. Our research can be useful in the field of management, journalism and psychology, given the trend toward interdisciplinary connections.

The theoretical significance of the study is determined by its contribution to discourse study, as ideation discourse is the new direction in the field of communication studies.

The key concept in our study is idea, which forms the basis for such term as ideation. Being a relatively new branch of studies in domestic linguistics, ideation discourse was studied by one of the Ukrainian scholar - Kaysina D. who defines it as a process and the result of cognitive-communicative interaction between communicants in the socio-cultural context of a public speech [8, p. 33].

Use of the term "key" in reference to the term "mode" is a central concept in frame analysis. "Keying" is the way communicants comprehend the essentials of what is happening [6, p. 43-44]. Serious mode of speech requires truth and conceptualizes the world as consistent and coherent [5]. Humor is a mood of disposition, characterized by a sensitivity or appreciation of ludicrous, absurd, incongruous, or comical events [11]. We may assume that incongruity is meant to be communicators' awareness of the incompatibility of the expected and actual development of the referential situation. There are main dimensions of humor: humor creativity which describes the behavior of a person who intentionally creates a humorous product, and humor appreciation which describes the behavior of a person who recognizes und understands humor from a cognitive-emotional position that results in the behavioral response of laughter [15, p. 37].

In the context of the study we identified initial rational, emotive, volitional rhetorical strategies as well as the ones focused on the recipient's subconsciousness [8, p.109-142]. Responsive strategies of communicative effect correlate with recipients' responsive communicative actions that are in the same spatiotemporal positions with the ideators (laughs, cries, applause, gestures, etc.) as well as in the different ones. According to the way of manifestation the abovementioned strategies are classified as verbal and nonverbal [8, p.196-207].

Having analyzed a selection of speeches on the opposite topics related to Business and Entertainment performed by the TED Talks speakers, we discovered that some presenters delivered their speeches only in serious tone, while the others tacked some jokes, funny stories or anecdotes on to their message, as a result, stirring up audience's emotions and responses. It is important to emphasize that regardless of the seriousness degree of the topic, speakers in both categories (Business and Entertainment) used elements of humor in their speeches, thereby intensifying an interest to the issue and emotional excitement.

The research approves that ideators consistently apply humorous mode at the beginning of their speech, aiming at getting into rapport with the audience. They continuously "fuel" their talks with humorous narratives, rhetoric questions, metaphors, jokes etc. - these all are verbal means of mode variation in an ideative speech; and gestures, mime, screen display etc., which we regard as non-verbal ones. Most of the speakers finish their speech with a powerful message, conveyed either in humorous or serious mode, sometimes even with the embodiment of both, affecting the recipient's will through explicit or implicit inducement placed in the context of humor.

The strategy of communicative effect that focuses on the rational sphere of recipient's consciousness is based on the fact that the ideator provides a certain thesis, which in most cases relates to the explication or implication of the problem of ideational speech, the explication or implication of the motivation of the idea and the benefits of its implementation. In this case, recipients have an opportunity to analyze the information provided, the arguments in favor and against, to take into account the sources of information referred to by the speaker.

An example of initial strategy that focuses on the sphere of emotions serves an abstract from America Farrera's speech, in which she brings up an issue of the person's identity. With the means of lexical repetitions she also touches upon the recipient's subconciousness. Her aim is to highlight that firstly was given the role because her personality was rated as unsuitable (too brown, too fat, too unsophisticated). She also stresses the word people to emphasize that she desires to represent the lives of real people in cinematography. This part of America's talk is delivered in a serious mode:

These were the kinds of roles that existed for someone like me. Someone they looked at and saw as too brown, too fat, too poor, too unsophisticated. These roles were stereotypes and couldn't have been further from my own reality or from the roles I dreamt of playing. I wanted to play people who were complex and multidimensional, people who existed in the center of their own lives. Not cardboard cutouts that stood in the background of someone else's (A. Ferrera).

However, she switches from a serious mode to humorous to relieve the tension:

But when I dared to say that to my manager - that's the person I pay to help me find opportunity - his response was, "Someone has to tell that girl she has unrealistic expectations." And he wasn't wrong. I mean, I fired him, but he wasn't wrong (Laughter) (A. Ferrera).

The ideator's humorous narration admits that even thought her manager's words wounded her feelings to the extent that she fired him, she still thinks that the manager had a point. Comical effect here is reached by the exaggeration of the situation.

An Australian actor and film producer David Wenham shares his insights into the seemingly mysterious alchemy of the acting process through his speech, and the following extract represents how he starts it:

I was once a lawyer, I was a criminal lawyer, I represented a number of notorious criminals. I also developed a two-thousanddollar-a-week cocaine habit. My marriage broke down, and $\boldsymbol{I}$ was sent to jail for concealing knowledge of a rather large importation of drugs. Before I was a lawyer, I was a priest, and before I was a priest, I was a soldier. In fact, I've been ten different soldiers. I've been a policeman. I beg pardon, four policemen, I think. ... I was God. (Laughter) Only once. (Laughter) I've been married more times than Elizabeth Taylor and I've been father to more kids than I can remember. (Laughter) My name is David and I am an actor (Laughter) (Applause) (D. Wenham).

The speaker's narrates using emotively colored speech with repetitions (repetition of a pronoun $I$ ) and comparisons. At first, the audience takes his story seriously, however starting with the words "Before I was a lawyer, I was a priest ..." the recipient starts to comprehend that the narrator's words contradict the norms and external reality, and the audience bursts into laughter and applause. By the use of a continuous repetition of the pronoun $I$, the author aims at leading us to confusion and makes us believe he is a lawyer, drug-dealer, policemen, priest and soldier all in one. At the end of this extract it becomes clear that being an actor means "living" 
the lives of the listed characters. One of the humorous elements that David used was a comparison of his character with a "Queen of Hollywood" in the 1950s Elizabeth Taylor. The actress has been married for eight times and was the mother of four children. By adjusting the audience to a humorous mode at the very beginning of the speech, the ideator establishes a contact that facilitates the perception of the idea delivered in a speech.

The extract outlined above serves a typical example of incongruity, i.e. disparity between the recipient's expectation and actual development of the referential situation.

Chip Conley's (C. Conley) speech demonstrates us the power of paronymy and the wordplay (ship a feature; deep ship) over the recipient's emotional sphere. He starts his talk with his true story from his introduction to Airbnb - the worldwide marketplace for arranging or offering lodgings, homestays or tourist experiences. The main idea of his speech is to show that despite an enormous gap between generations, we still have something to learn from each other.

It was my third day on the job at a hot Silicon Valley start-up in early 2013. I was twice the age of the dozen engineers in the room. I'd been brought in to the company because I was a seasoned expert in my field, but in this particular room, I felt like a newbie amongst the tech geniuses. I was listening to them talk and thinking that the best thing I could do was be invisible. And then suddenly, the 25-year-old wizard leading the meeting stared at me and asked, "If you shipped a feature and no one used it, did it really ship?" (Laughter)

"Ship a feature"? In that moment, Chip knew he was in deep ship (Laughter) (C. Conley).

What the ideator makes us understand is that the product managers' professional slang (to ship a feature) was completely novel for him. To achieve a comic effect he applies the word ship in an absolutely different context instead of using expletives.

We refer to the speech of Luvvie Ajayi again to illustrate the use of figurative comparison (being the domino) in the example that follows:

I am the person who is looking at other people, like, "I need you to fix it." That is me. I want us to leave this world better than we found it. And how I choose to effect change is by speaking up, by being the first and by being the domino. For a line of dominoes to fall, one has to fall first, which then leaves the other choiceless to do the same. And that domino that falls, we're hoping that, OK, the next person that sees this is inspired to be a domino. Being the domino, for me, looks like speaking up and doing the things that are really difficult, especially when they are needed, with the hope that others will follow suit (L. Ajayi).

Luvvie Ajayi chooses the idea of domino to illustrate the process of making changes, for making the difference. As she explains, that is enough for one person to speak up in order to make the change for better (to be the first domino) and other people will be inspired to do the same.

Another example of incongruity is reflected in Christopher Bell's speech about an equal respect and value our society should give to females as compared with males:

My kid's athletic. She is strong and fast and has great balance and good body control. She is a three-time, back-to-back-to-back state champion in Shaolin Kempo. At nine years old, she is already halfway to a black belt. My daughter is athletic.

Now, when a man who is six feet two and 265 pounds stands in front of you and says his daughter is athletic, you might think that's a reflection of him. It is not (Laughter) (C. Bell).

Here incongruity lies in the contrast between the speaker's heavyset appearance and the message he was delivering. This shows us that the audience perceives self-critical joke positively and reacts with laughter.

In Tim Urban's (T. Urban) speech the effect on the will is exercised through explicit or an implicit inducement placed in the context of humor.

So I think we need to all take a long, hard look at that calendar. We need to think about what we're really procrastinating on, because everyone is procrastinating on something in life. We need to stay aware of the Instant Gratification Monkey. That's a job for all of us. And because there's not that many boxes on there, it's a job that should probably start today. Well, maybe not today, but... (Laughter) You know. Sometime soon. Thank you (Applause) (T. Urban).

Two imperative statements prompt the audience to implement his idea into practice with the help of two contrasting tips: serious (we need to all take a long, hard look at that calendar. We need to think about what we're really procrastinating on, because everyone is procrastinating on something in life) and humorous one (it's a job that should probably start today. Well, maybe not today, but... you know. Sometime soon).

Thus, the communicative effect on the recipient's will is embodied with the help of imperative, modal verbs of necessity, performative verbs and noun constructions as part of the statements. Often, the communicative effect on the will is realized in parallel with other rhetorical strategies aimed at other areas of recipient's consciousness and subconsciousness.

Responsive strategy of communicative effect is an inevitable part of communication, which is an intersubjective interaction between an ideator and recipients. During this interaction common and different communicative meanings are formed. Thus, recipients' responsive actions embody these meanings, and so provide an opportunity to evaluate and rate the success of communicative effect created by an ideator. Responsive actions, as well as ideator's initial actions, are directed by their interests, needs and desires, and are strategy oriented [8, p. 196]. Responsive strategies of communicative effect are divided into instant and delayed. According to the way of manifestation the abovementioned strategies are classified as verbal and non-verbal. Instant responsive strategies are carried out by the audience, which is present at the TED conference. Delayed responsive strategies are carried out by the recipients, who visit TED platform online.

The total amount of views of an English ideation speech published on TED-platform is considered to be non-verbal responsive actions. In our study, we use the total number of views provided by the TED community on the Internet platform for each video separately, and an average monthly number of views. We take into consideration both criteria, because the total number of views may be higher in those ideational speeches that have been published earlier than others. Also the average monthly number of views, according to observations, is higher in video recordings of speech, as soon as they appear on the Internet platform TED, over time, this figure may fall.

In order to evaluate success of the selected speeches, we separated the speeches, which have the total number of views less than 1 million; more than 30 million; 1 - 2 million; $2-5$ million; $5-7$ million (Fig. 1a); average monthly number of views - less than $100000 ; 100000$ - $150000 ; 150000$ - 250 000; 500000 - million(Fig.1b). 


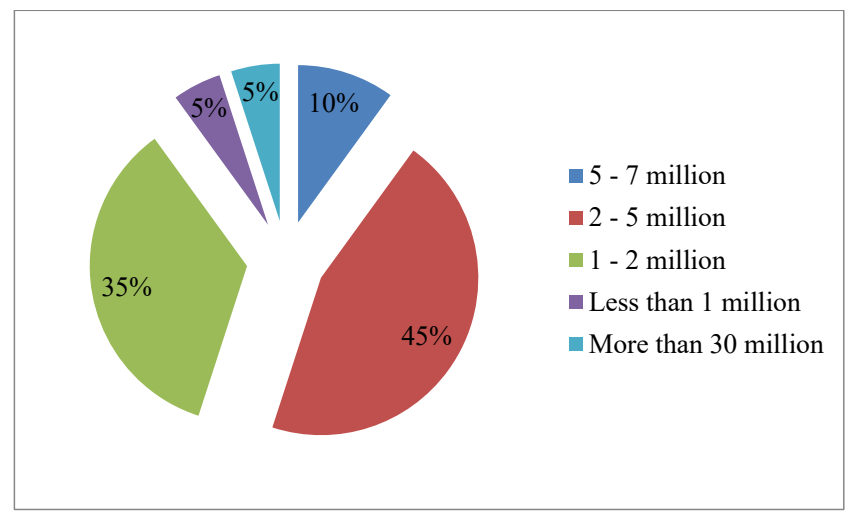

Fig. 1a. Communicative success of speeches according to the total number of views

We also counted each instant responsive action separately, as well as their total sum, for the evaluation of the speech success. Instant responsive actions that were analyzed are: applause, cheers, laughter, and murmur. According to the conducted analysis, laughter is the most common instant responsive reaction, its total sum is 161 . Second place takes applause, total number of which is 51. Thus, we may assume, that the use of humor, particularly, the variation of humorous and serious mode is the key in reaching the communicative success.

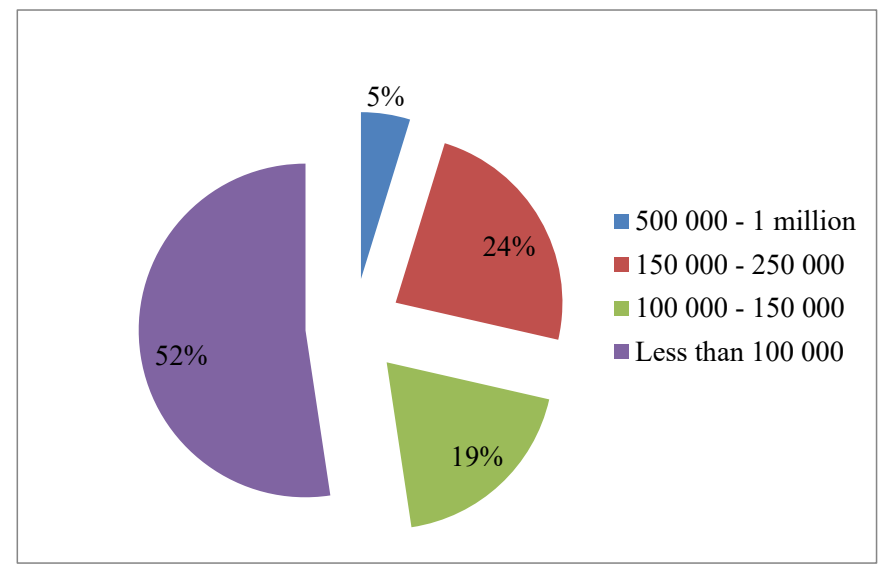

Fig. 1b. Communicative success of speeches according to the average monthly number of views

Table 1.

\begin{tabular}{|c|l|l|c|c|c|c|c|c|}
\hline № & \multicolumn{1}{|c|}{ Ideator } & \multicolumn{1}{|c|}{ Name of speech } & $\begin{array}{c}\text { Total number } \\
\text { of views }\end{array}$ & $\begin{array}{c}\text { Average monthly } \\
\text { number of views }\end{array}$ & Applause & Cheers & Laughter & Murmur \\
\hline 1 & $\begin{array}{l}\text { America } \\
\text { Ferrera }\end{array}$ & $\begin{array}{l}\text { My identity is a superpower }- \\
\text { not an obstacle }\end{array}$ & 2340494 & 111024 & 4 & 0 & 3 & 0 \\
\hline 2 & Carla Harris & $\begin{array}{l}\text { How to find a person who can } \\
\text { help you get ahead at work }\end{array}$ & 3522544 & 125805 & 1 & 0 & 3 & 0 \\
\hline 3 & Chip Conley & $\begin{array}{l}\text { What baby boomers can learn } \\
\text { from millennials at work }- \\
\text { and vice versa }\end{array}$ & 2464438 & 123222 & 1 & 0 & 3 & 0 \\
\hline 4 & $\begin{array}{l}\text { Christopher } \\
\text { Bell }\end{array}$ & Bring on female superheroes! & 1240210 & 22549 & 1 & 0 & 6 & 0 \\
\hline 5 & $\begin{array}{l}\text { Danielle } \\
\text { Feinberg }\end{array}$ & $\begin{array}{l}\text { The magic ingredient that } \\
\text { brings Pixar movies to life }\end{array}$ & 3080095 & 57038 & 1 & 0 & 4 & 0 \\
\hline 6 & $\begin{array}{l}\text { David } \\
\text { Wenham }\end{array}$ & Why I became an actor & 60388 & 5032 & 3 & 0 & 12 & 0 \\
\hline 7 & $\begin{array}{l}\text { Douglas } \\
\text { Rushkoff }\end{array}$ & $\begin{array}{l}\text { How to be “Team Human” in } \\
\text { the digital future }\end{array}$ & 1682411 & 84120 & 1 & 0 & 7 & 0 \\
\hline 8 & $\begin{array}{l}\text { Jennifer Zhu } \\
\text { Scott }\end{array}$ & $\begin{array}{l}\text { Why you should get paid for } \\
\text { your data }\end{array}$ & 1310644 & 218440 & 1 & 0 & 6 & 0 \\
\hline 9 & Jude Kelly & $\begin{array}{l}\text { Why women should tell the } \\
\text { stories of humanity }\end{array}$ & 1256510 & 29221 & 4 & 1 & 9 & 0 \\
\hline
\end{tabular}




\begin{tabular}{|c|c|c|c|c|c|c|c|c|}
\hline 10 & Julia Dhar & $\begin{array}{l}\text { How to disagree productively } \\
\text { and find common ground }\end{array}$ & 4179099 & 219952 & 1 & 0 & 4 & 0 \\
\hline 11 & $\begin{array}{l}\text { Joachim de } \\
\text { Posada }\end{array}$ & Don't eat the marshmallow! & 3628241 & 26875 & 1 & 0 & 5 & 0 \\
\hline 12 & \begin{tabular}{|l|} 
Leah \\
Georges \\
\end{tabular} & $\begin{array}{l}\text { How generational stereotypes } \\
\text { hold us back at work }\end{array}$ & 2285286 & 81617 & 1 & 0 & 10 & 0 \\
\hline 13 & $\begin{array}{l}\text { Luvvie } \\
\text { Ajayi }\end{array}$ & $\begin{array}{l}\text { Get comfortable with being } \\
\text { uncomfortable }\end{array}$ & 4983697 & 166123 & 5 & 0 & 14 & 0 \\
\hline 14 & \begin{tabular}{|l|} 
Manoush \\
Zamorodi \\
\end{tabular} & $\begin{array}{l}\text { How boredom can lead to } \\
\text { your most brilliant ideas }\end{array}$ & 4487456 & 118090 & 2 & 0 & 8 & 0 \\
\hline 15 & $\begin{array}{l}\text { Negin } \\
\text { Farsad }\end{array}$ & $\begin{array}{l}\text { A highly scientific taxonomy } \\
\text { of haters }\end{array}$ & 1433554 & 36757 & 2 & 1 & 16 & 0 \\
\hline 16 & Paul Tasner & $\begin{array}{l}\text { How I became an } \\
\text { entrepreneur at } 66\end{array}$ & 2218890 & 65216 & 5 & 2 & 10 & 0 \\
\hline 17 & $\begin{array}{l}\text { Priti } \\
\text { Krishtel }\end{array}$ & $\begin{array}{l}\text { Why are drug prices so high? } \\
\text { Investigating the outdated US } \\
\text { patent system }\end{array}$ & 1485604 & 247600 & 3 & 0 & 5 & 1 \\
\hline 18 & \begin{tabular}{|l|} 
Reshma \\
Saujani \\
\end{tabular} & $\begin{array}{l}\text { Teach girls bravery, not } \\
\text { perfection }\end{array}$ & 5109267 & 92895 & 5 & 0 & 0 & 0 \\
\hline 19 & \begin{tabular}{|l} 
Sara \\
Sanford
\end{tabular} & $\begin{array}{l}\text { How to design gender bias } \\
\text { out of your workplace }\end{array}$ & 1256206 & 83747 & 4 & 0 & 5 & 1 \\
\hline 20 & Susan David & $\begin{array}{l}\text { The gift and power of } \\
\text { emotional courage }\end{array}$ & 7203171 & 232360 & 3 & 0 & 5 & 0 \\
\hline 21 & Tim Urban & $\begin{array}{l}\text { Inside the mind of a master } \\
\text { procrastinator }\end{array}$ & 39062315 & 737024 & 2 & 0 & 26 & 0 \\
\hline
\end{tabular}

Taking into consideration instant responsive actions of the "live" audience present at the TED conference, the following speakers managed to achieve a communicative effect: Tim Urban "Inside the mind of a master procrastinator" - 28; Negin Farsad "A highly scientific taxonomy of haters" - 19; Paul Tasner "Paul Tasner "How I became an entrepreneur at 66" - 19; Luvvie Ajayi "Get comfortable with being uncomfortable" - 19 (Fig. 2). As the results show, there is an absolutely successful speech by Tim Urban "Inside the mind of a master procrastinator", which has the highest amount of delayed responsive actions, both the total number of views and average monthly number of views, as well as instant responsive actions. Another partly successful speech according to instant and delayed actions is by Susan David Susan David "The gift and power of emotional courage", as she has received only 8 instant responsive actions during live TED conference.

The study results are summarised in the following conclusions. Ideator's verbal and non-verbal actions are considered to be rhetoric strategies. Initial rhetoric strategies of communicative effect, carried out by the ideators of TED-platform in both serious and humorous mode, are focused on different spheres of consciousness: rational thinking, emotions, volition and subconsciousness. Rhetorical strategies focused on the rational thinking include explanation, narration, description, exposition. Rhetorical strategies focused on the sphere of emotions subordinate declaring strategies and emotive coloring. Rhetorical strategies focused on recipient's volition are usually implemented by the use of imperative form of a verb. Rhetorical strategies focused on subconsciousness are actualized by different kinds of verbal repetition.

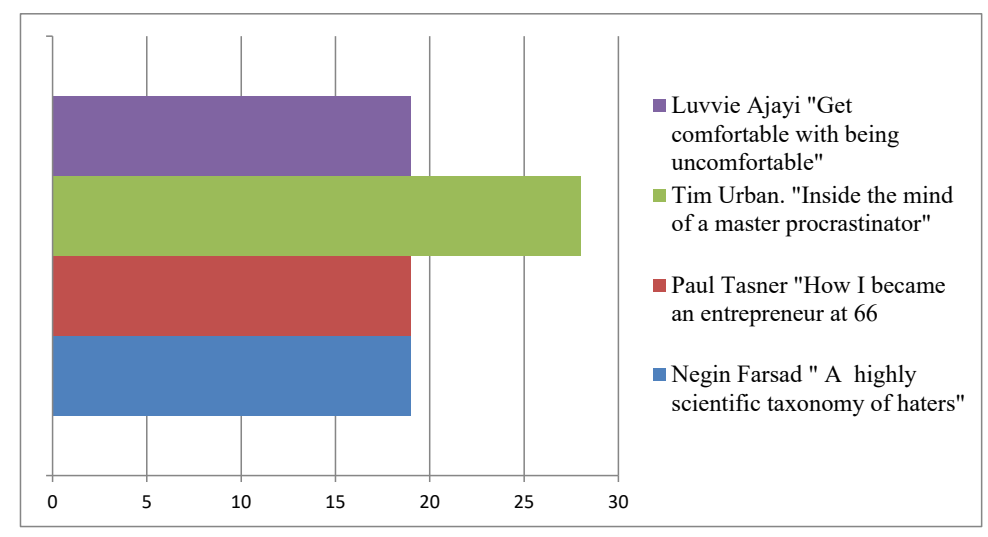

Figure 2. The most successful speeches according to the number of instant responsive actions

Responsive strategies of communicative effect correlate with recipients' responsive communicative actions that are in the same spatiotemporal positions with the ideators (laughs, cries, applause, gestures, etc.) as well as in the different ones.

$96 \%$ (= 20) of the selected speeches in our study demonstrate that ideation activity is set forth with the means of variation of humorous and serious tonality. The strategy of explanation is widely used in serious tonality with the implementation of semantically coherent statements conjuncted in an explanatory way aiming at informing recipients about the problem or idea of the speech. 
Transition from serious to humorous tonality is also provided by multimodal strategies of communicative effect, which include the use of any supporting material: video, audio tracks, photos, graphic presentations, tables, graphs, diagrams, drawings, etc.

Communicative success of the selected speeches has been evaluated with the help of inferential analysis taking into account instant and delayed responsive actions, in particular total number of the recording views, average monthly number of views; laughter, applause, cheers, murmur. An average total amount of views ranges from 2 to 5 million, and is equal to $45 \%$ from all the selected speeches. The most successful speeches received $19-28$ instant responsive actions.

The prospect of our further investigation is to conduct a detailed analysis of non-verbal means of communication in the context of communicative effect.

\section{Література:}

1. Качмар О. Ю. Діяльнісна інтерпретація дискурсу: когнітивний аспект. Наукові записки Наиіонального університету «Острозька академія». Серія : Філологічна. 2015. Вип. 51. С. 39-42. URL: http://nbuv.gov.ua/UJRN/Nznuoaf_2015_51_17

2. Anderson C. TED talks: the official TED guide to public speaking. Boston : Houghton Mifflin Harcourt, 2016.

3. Attardo S. Linguistic theories of humour. Berlin - N.Y. : Mouton de Gruyter, 1994. 426 p.

4. Cambridge Dictionary. URL: https://dictionary.cambridge.org/dictionary/english/idea? q=IDEA

5. Farner G. Literary Fiction: The Ways We Read Narrative Literature, 2014. URL: https://books.google.com.ua/books?id=qXXHAgAA QBAJ\&pg=PT61\&lpg=PT61\&dq $=$ Serious + mode + of + speech\&source $=$ bl\&ots $=$ i3MyUwI5Xn\&sig=ACfU3U3HSLmv10EpMwLaRfEjFQ ixRLzKw\&hl=ru\&sa=X\&ved=2ahUKEwjB_rfn2PnmAhWyioKHVoIApMQ6AEwC3oECAoQAQ\#v=onepage\&q=Serious\%20mode $\% 20$ of $\% 20$ speech\&f $=$ false

6. Goffman E. Frame Analysis: An Essay on the Organization of Experience. Boston : Northeastern University Press, 1986.586 p.

7. Johnson M. The Body in the mind (the bodily basis of meaning, imagination, and reason). Chicago, L. : The Un-ty of Chicago Press, 1987. 233p.

8. Kaysina D. English ideation discourse: strategies of communicative effect (based on TED Internet Platform) PhD. V. N. Karazin Kharkiv National University, 2018. 318 p.

9. Lakoff R. T. Persuasive discourse and ordinary conversation, with examples in advertising. Analizing Discourse: Text and Talk / Tannen D. (Ed.).Georgetown: Georgetown University Press, 1981. P. 25-42.

10. Makarov M. Osnovu Teorii Diskursa, 2003. URL: http://yanko.lib.ru/books/cultur/makarov-osnovu teorii_diskursa-81.pdf

11. McGee P. Humor and aging, 1986. URL: https://www.sciencedirect.com/book/9780125137904/humor-and-aging

12. Morozova O. Speech Manipulation in a Multi-Party Interactive Field. Вісник Київського національного лінгвістичного університету. Сер.: Філологія. 2013. Т. 16. № 2. С. 84-91.

13. Oxford Dictionaries. URL: https://en.oxforddictionaries.com/definition/ideation

14. Schiffrin D., Tannen D. and Hamilton H. The Handbook of discourse analysis, 2001. 874 p.

15. Temple R. Critical and Creative Thinking and Humor. Critical and Creative Thinking Capstones Collection, 1992. URL: https:// scholarworks.umb.edu/cgi/viewcontent.cgi?article $=1296 \&$ context $=$ cct_capstone

16. Van Dijk T. A., Date W. K. Strategies of discourse comprehension. New York : Academic Press, 1983. 389 p.

\section{Джерела ілюстративного матеріалу:}

17. Ajayi L. Get comfortable with being uncomfortable. URL: https://www.ted.com/talks/luvvie_ajayi_get_comfortable_with_being uncomfortable

18. Bell C. Bring on the female superheroes! URL: https://www.ted.com/talks/christopher_bell_bring_on_the_female_superheroes

19. Conley, C. What baby boomers can learn from millennials at work - and vice versa. URL: $\bar{h}$ ttps://www.ted.com/talks/chip_conley_ what_baby_boomers_can_learn_from_millennials_at_work_and_vice_versa

20. David S. The gift and power of emotional courage. URL : https://www.ted.com/talks/susan_david_the_gift_and_power_of_ emotional courage

21. Dhar J. How to disagree productively and find common ground. URL: https://www.ted.com/talks/julia_dhar_how_to_disagree_ productively and find common ground

22. Ferrera A. My identity is a superpower - not an obstacle. URL: https://www.ted.com/talks/america_ferrera_my_identity_is_a_ superpower_not_an_obstacle

23. Harris C. How to find a person who can help you get ahead at work. URL: https://www.ted.com/talks/carla_harris_how_to_find_the person_who_can_help_you_get_ahead_at_work

24. Urban T. Inside the mind of a master procrastinator. URL: https://www.ted.com/talks/tim_urban_inside_the_mind_of_a_master_ procrastinator

25. Wenham D. Why I became an actor. URL: https://www.ted.com/talks/david_wenham_why_i_became_an_actor 